\title{
Test Rig for Emulation of Turbocharged SOFC Plants
}

\author{
Mario L. Ferrari ${ }^{*}$, Matteo Pascenti, Alessio Abrassi \\ University of Genoa, Via Montallegro 1, 16145, Genova, Italy
}

\begin{abstract}
This work is devoted to an emulator test rig designed for experimental analysis on SOFC-based plants pressurised by a turbocharger. The utilization of a turbocharger for SOFC pressurization aims to reduce the machine costs, due to the large mass production of this component. This emulator rig is an essential plant to perform tests on the component integration, dynamic operations, control system development and prevention of risky operative conditions (e.g. surge). These are essential issues to be solved before developing expensive complete prototypes and the related commercialization. This experimental plant is based on a pressure vessel for emulating the thermal (combustor and inert ceramic material) and fluid dynamic (the volume) responses. The vessel pressurisation is obtained with a turbocharger, where the exhaust flow operating in the turbine powers the compressor. The plant is also equipped with a recuperator and with different valves for control and flexibility reasons (bleed, compressor/turbine bypass, and recuperator bypass). Preliminary experimental results are included in this work focusing attention on the turbocharger choice and on the component constraints. In details, these are the necessary experiments for choosing the suitable machine for the rig (with a good surge margin for this component coupling).
\end{abstract}

\section{Introduction}

Due to the power generation issues related to pollution decrease, efficiency increase and cost of primary sources [1] (e.g. the fuel), the Solid Oxide Fuel Cell (SOFC) technology is promising for future stationary applications. However, the benefits related to efficiency and emission targets (and the obvious effects on costs) can be significantly improved through SOFC pressurization [2]. For these reasons, several researchers and companies are involved in activities for designing hybrid systems based on the coupling of SOFCs with a microturbine [3]. Although significant results are available in this topic, including Mitsubishi Hitachi Power Systems that declared in 2018 to have received a first order for these SOFC systems [4], some constraints are limiting their wide development. These issues regard not only technical aspects to be improved (e.g. component constraints, reliability, control problems, etc. [5]), but also cost aspects that a future mass production could be unable to solve [6]. While different works are under development for SOFC layout

\footnotetext{
*Corresponding author: mario.ferrari@unige.it
} 
and material costs, attention should to be also focused on cost decrease for plant components based on traditional technology. For this reason, this paper proposes the SOFC pressurization with a turbocharger instead of a microturbine, exploiting the mass production benefits of these components. Although the utilization of a turbocharger instead of a microturbine is not able to maximize the efficiency increase due to the exhaust flow harvesting, the cost reduction (few hundreds of euro even for the largest turbochargers against more than one thousands of euro/kW for a microturbine $[7,8]$ ) could motivate the choice if properly managed during operations.

Since real prototypes based on SOFCs are very expensive and critical for damage risks, several institutions developed emulator test rigs based on the coupling of the turbomachine components with pressure vessels designed for the fuel cell emulation. In details, it is important to cite the "Hyper" plant by NETL (including two pressure vessels and a flexible control system) [9], the T100 based rig by the University of Genoa (equipped with an anodic recirculation system and a steam injection device for chemical composition emulation) [10], and the emulator rig by DLR (equipped with a high temperature vessel including a cooling system) [11]. These plants were able to produce significant results on different issues, such as SOFC/turbine matching, surge prevention, dynamic and control system aspects [12]. For this reason, this paper focuses attention on the design and installation activities for the development of an emulator rig to study turbocharged SOFC systems, as planned in the Bio-HyPP H2020 EU project [13].

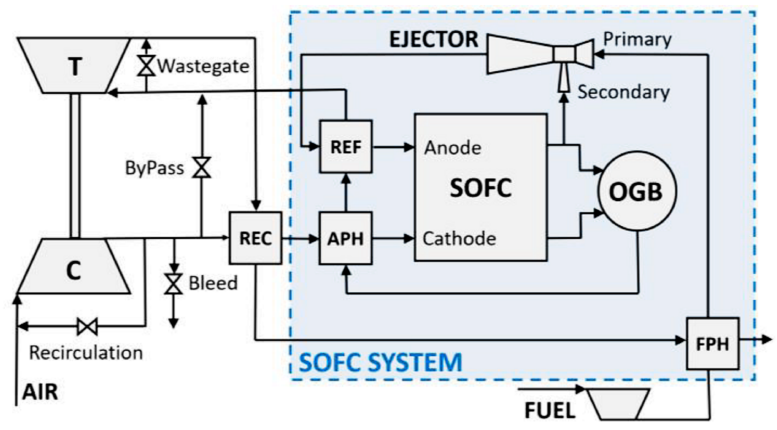

Figure 1: Layout of the turbocharged SOFC system.

\section{System layout}

The system layout is based on the coupling of an SOFC system with a turbocharger (Fig.1). In details, the air flow is: (i) managed by the turbocharger compressor (C), (ii) heated by the recuperator (REC), and (iii) fed to the SOFC system. Moreover, before entering the cathode side, a further heating is present: although it is represented by the air pre-heater (APH) in Fig.1, it is just an internal thermal exchange in the SOFC ceramic ducts. The fuel (biogas in the Bio-HyPP project [13]) is compressed, heated in the fuel preheater and diverted to the anodic ejector primary duct. This ejector, included to generate a flow recirculation in the anodic side, is essential to produce the proper flow and temperature conditions [14] in the reformer (REF), that is located upstream of the SOFC anodic inlet. The SOFC outlet flows are mixed in the off-gas burner (OGB) for the combustion of the fuel content not completely converted in SOFC. The OGB outlet flow is used for air and reformer heating upstream of the SOFC system outlet duct. Finally, this exhaust flow is diverted to the turbocharger turbine located upstream of the hot sides of the recuperator and the $\mathrm{FPH}$. 
This layout was designed couple the cost decrease of a mass production turbocharger with benefit related to efficiency increase due to SOFC pressurization (about $+11 \%$ efficiency switching from 1 bar to 5 bar [15]). However, comparing the system performance with a micro gas turbine hybrid plant, the generated power is lower $(10 \%$ $15 \%$ ) due to the missing electrical generator.

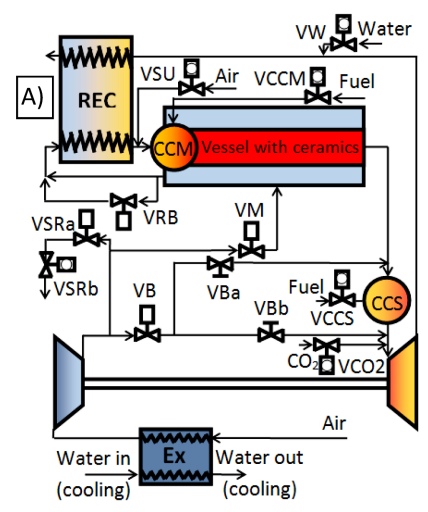

Figure 2: A) Test rig layout,
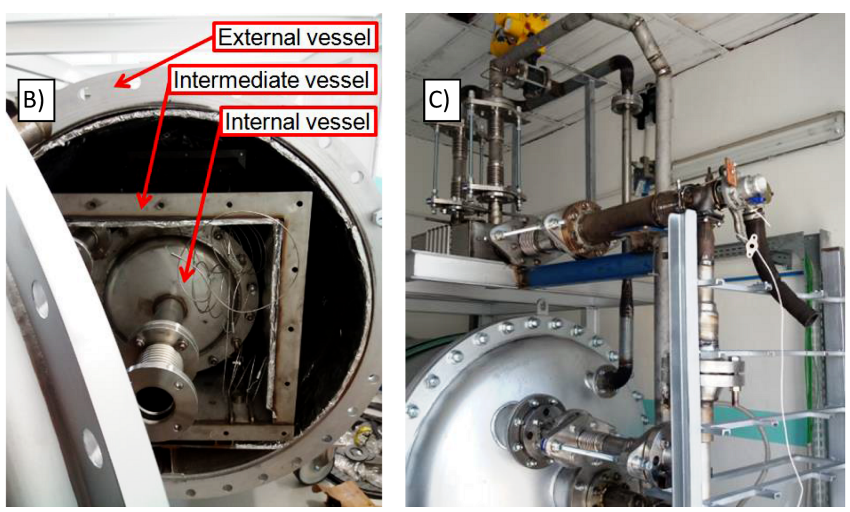

installation activities.

\section{Test rig layout}

While the previous section shows a summary of the reference system, this section describes a new test rig designed for studying the plant shown in Section 2. To avoid costs and risks of a complete prototype, the University of Genoa has started the experimental analysis on turbocharged SOFC plants with a proper emulator rig (Fig.2). This facility was developed in the framework of the Bio-HyPP H2020 project [13] to analyze and improve specific issues, such as machine/SOFC interaction, component transient performance, control system aspects and risk prevention (e.g. surge, thermal stress, overspeed), etc. The test rig is composed of a commercial turbocharger connected to a pressure vessel for SOFC emulation (Fig.2 - part A). This component includes a burner (CCM) to generate SOFC temperature conditions and inert ceramic materials to emulate the SOFC thermal capacitance. This device is composed of three different vessels (Fig.2- part B): the external tank (1.2 m diameter, $2.5 \mathrm{~m}$ length and torispherical ends) was designed to sustain the pressure stress and the weight at low temperature conditions (it is cooled by the compressor outlet flow), the intermediate skin is based on a stainless steel squared section to support internal thermal insulation panels, the internal vessel is a high temperature pipe including the ceramic materials in the form of $20 \mathrm{~mm}$ diameter alumina spheres. Moreover, the rig includes a recuperator (REC) for the thermal recovering, an air/water heat exchanger (Ex) for ambient temperature variation emulation and control, and an additional burner for the system start-up (CCS).

The emulator rig (Fig.2 - part C) is equipped with additional devices for test and control reasons: (i) the water injection line (managed by the VW valve) for cooling the recuperator inlet duct (hot side) in case of excessive temperature, (ii) the $\mathrm{CO}_{2}$ injection line for emulating operations with biogas of different compositions (managed by the $\mathrm{VCO} 2$ valve), (iii) the start-up air duct for feeding compressed air during start-up operations (managed by the VSU valve), (iv) the compressor/turbine bypass (managed by the VB valve - two options are included with $\mathrm{VBa}$ and $\mathrm{VBb}$ manual valves) for rotational speed and SOFC temperature control, (v) the recuperator bypass line (managed by the VRB valve) for a 
further thermal management option during start-up/shutdown operations, (vi) the bleed line (managed by both controlled - VSRb - and on/off valves - VSRa), and (vii) an additional valve in the mail line (VM) for air management during specific transient operations. Moreover, the plant includes probes to measure mass flow rate, pressure and temperature in the different ducts and the turbocharger rotational speed.

An important configuration to be mentioned for a full system emulation is the cyberphysical mode (already successfully used in [10]). This approach is based on a real-time model (running in parallel with the rig) including the components not physically installed in the plant (the fuel cell, the reformer, the OGB and the thermal exchanges of the SOFC system). The model receives (as inputs) in real-time mode the values of the vessel inlet mass flow and temperature and calculate the SOFC performance including the temperatures. So, the plant can be controlled (the CCM fuel) to match the actual temperature with the calculated ones (usually at the SOFC inlet cathode duct) to obtain in the rig the dynamic effect of an SOFC system. The model can be also used to evaluate other properties, such as the amount of $\mathrm{CO}_{2}$ to be injected to emulate a system fed by biogas.

\section{Preliminary experimental results}

Preliminary experimental activities were carried out bypassing (through the VB and $\mathrm{VBa}$ valves) the vessel for SOFC emulation (closing the VM valve and the vessel outlet duct). These tests were necessary to choose a turbocharger which is able to operate in the proposed SOFC system emulator. The results were obtained using two machines by Garrett Advancing Motion (turbochargers supplied thanks to a previous informal agreement between the company and the University of Genoa).

An initial test presented here was carried out on the GT0634 machine (Turbocharger 1). The test was started with VSRa and VB in intermediate positions (VSRb in the fully open position). The VSU valve was opened to inject about $10 \mathrm{~g} / \mathrm{s}$ of air flow and the combustor was ignited with natural gas to reach about $1093 \mathrm{~K}$ for the Turbine Inlet Temperature (TIT). A second test was performed on the GT1238Z machine (Turbocharger 2). Since this turbocharger is based on a water cooling configuration, it was possible to reach a TIT value close to $1193 \mathrm{~K}$.

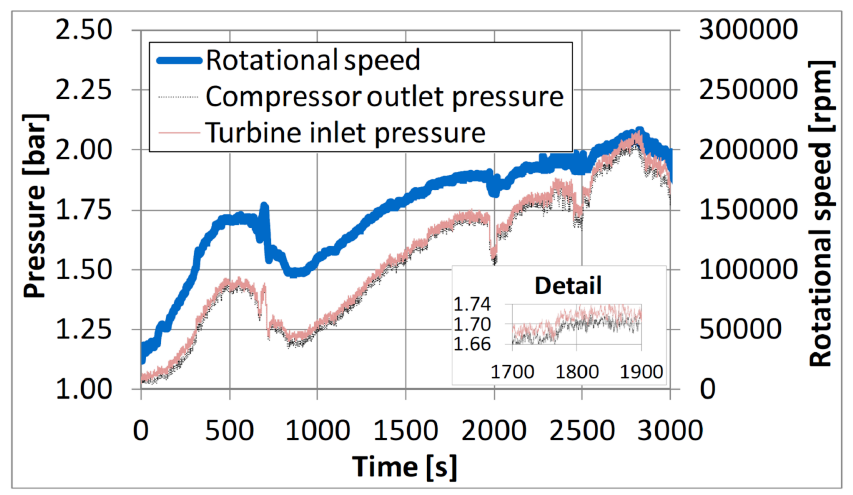

Figure 3: Pressure values (with a detail) and rotational speed for the Turbocharger 1.

\subsection{Turbocharger 1}

Figure 3 demonstrates that this machine is not the best choice for the emulator rig since the turbine inlet pressure is higher (about 20-30 mbar) than the values at the compressor outlet. This was obtained injecting the start-up air flow from an external compressor. This 
20-30 mbar value is significant for this test because higher than the sum of the possible maximum measurement errors of the two pressure probes. So, the bleed valve cannot be closed without generating surge conditions, because it is not possible to obtain higher pressure values at the compressor outlet in stable conditions.
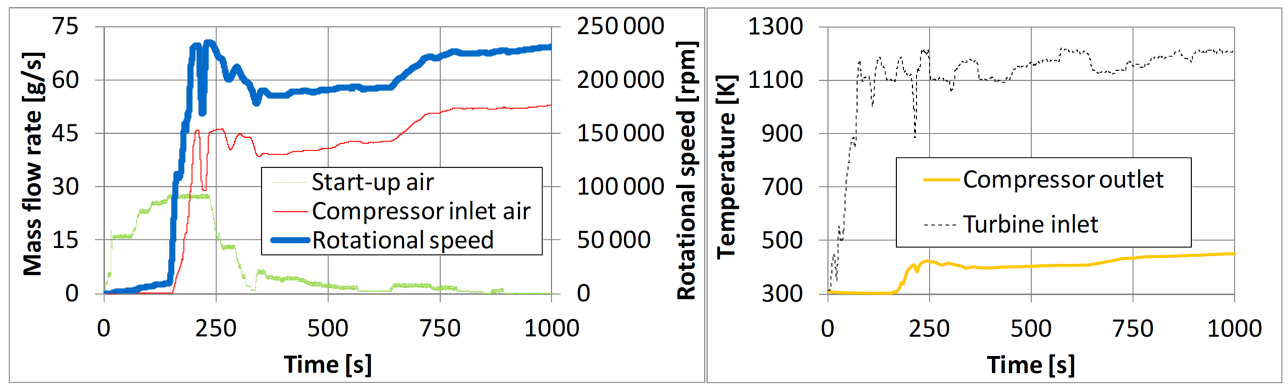

Figure 4: Mass flow rate values (start-up and compressor inlet air), rotational speed, and temperatures at the compressor outlet and turbine inlet for the Turbocharger 2.

\subsection{Turbocharger 2}

In this case, the start-up phase was carried out with the VSRb fully closed and the VB and $\mathrm{VBa}$ fully open. Initially, the start-up air flow was injected and the burner was ignited with natural gas. No significant rotational speed values were obtained in the initial $140 \mathrm{~s}$ due to a large amount of the start-up air flow diverted to the compressor. So, Figure 4 shows a null mass flow rate value by the compressor inlet probe because the sensor is not able to perform reverse-flow measurements. Then, when the start-up air mass flow rate reached higher values than $26 \mathrm{~g} / \mathrm{s}$ the rotational speed suddenly increased to 200,000 rpm and higher values. Moreover, the temperature measured at the compressor outlet duct (Fig.4) confirmed the effective operation of this turbocharger: a significant increase showed that the air was flowing correctly and the machine was not in surge condition.

The most significant aspect of this discussion is shown by the second part of the start-up phase (after about $237 \mathrm{~s}$ from the beginning) related to the start-up air flow decrease. So, Fig.4 shows that it was possible to nullify this air mass flow rate while maintaining the turbocharger in full operation. No unstable behavior due to surge event was detected.

\section{Conclusions}

This paper shows a new emulator rig for experimental tests on SOFC systems pressurized by a turbocharger. The rig was installed by the University of Genoa in the framework of the Bio-HyPP H2020 EU project [13]. The main results presented in this paper are discussed in the following points.

- The turbocharged SOFC system layout is presented focusing the attention on the benefits obtainable from SOFC pressurization by a turbocharger.

- The emulator rig layout is presented considering the details of the pressure vessel for SOFC emulation: three different vessels (external size: $1.2 \mathrm{~m}$ diameter, $2.5 \mathrm{~m}$ length and torispherical ends).

- $\quad$ The cyber-physical mode (SOFC real-time model operating in parallel with the rig) is presented.

- The preliminary experimental results are presented to show that the GT0634 is not the best option for the turbocharged SOFC layout application because turbine inlet pressure is higher (about 20-30 mbar) than the values at the compressor outlet. 
However, since the GT1238Z has a good surge margin, it was chosen for future emulation tests.

These planned experimental activities will range from analyses on the SOFC/turbocharger interaction (especially in transient conditions) to control system development activities considering risk condition preventions.

This project has received funding from the European Union's Horizon 2020 research and innovation programme under grant agreement No 641073, Bio-HyPP project (http://www.bio-hypp.eu).

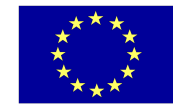

\section{References}

1. C.S. Wang, J.Y. Yan, H.J. Jia, J.Z. Wu, J.C. Yu, T. Xu, Zhang Y., Renewable and distributed energy integration with mini/microgrids, Applied Energy, 237, 920-923 (2019)

2. H. Mohammed, A. Al-Othman, P. Nancarrow, M. Tawalbeh, M. El Haj Assad, Direct hydrocarbon fuel cells: A promising technology for improving energy efficiency, Energy, 172, 207-219 (2019)

3. A. Cuneo, V. Zaccaria, D. Tucker, A. Sorce, Gas turbine size optimization in a hybrid system considering SOFC degradation, Applied Energy, 230, 855-864 (2018)

4. MHPS wins first order for integrated SOFC/gas turbine hybrid unit. Fuel Cells Bulletin, 6 (2018)

5. X. Zhang, H. Keramati, M. Arie, F. Singer, R. Tiwari, A. Shooshtari, M. Ohadi, Recent developments in high temperature heat exchangers: A review, Frontiers in Heat and Mass Transfer, 11, 1-14 (2018)

6. D. Saebea, L. Magistri, A.F. Massardo, A. Arpornwichanop, Cycle analysis of solid oxide fuel cell-gas turbine hybrid systems integrated ethanol steam reformer: Energy management, Energy, 127, 743-755 (2017)

7. R.H. Staunton, B. Ozpineci, Microturbine Power Conversion Technology Review. Oak Ridge National Laboratory (2003)

8. W.P.J. Visser, S.A. Shakariyants, M. Oostveen, Development of a $3 \mathrm{~kW}$ Micro Turbine for CHP Applications, GT2010-22007, ASME Turbo Expo 2010, Glasgow, UK (2010)

9. V. Zaccaria, D. Tucker, A. Traverso, Transfer function development for SOFC/GT hybrid systems control using cold air bypass, Applied Energy, 165, 695-706 (2016)

10. F. Caratozzolo, M.L. Ferrari, A. Traverso, A.F. Massardo, Emulator rig for SOFC hybrid systems: Temperature and power control with a real-time software, Fuel Cells, 13, 11231130 (2013)

11. M. Hohloch, A. Huber, M. Aigner, Experimental Investigation of a SOFC/MGT Hybrid Power Plant Test Rig: Impact and Characterization of a Fuel Cell Emulator. ASME Paper GT2016-57747, ASME Turbo Expo 2016, Seoul, South Korea (2016)

12. I. Rossi, A. Sorce, A. Traverso, Gas turbine combined cycle start-up and stress evaluation: A simplified dynamic approach, Applied Energy, 190, 880-890 (2017)

13. www.bio-hypp.eu [last access: 23rd April 2019]

14. A. Sorce, A. Greco, L. Magistri, P. Costamagna, FDI oriented modeling of an experimental SOFC system, model validation and simulation of faulty states. Applied Energy, 136, 894908 (2014)

15. M. Henke, J. Kallo, K.A. Friedrich, W.G. Bessler, Influence of Pressurisation on SOFC Performance and Durability: A Theoretical Study, Fuel Cells, 11, 581-591 (2011) 